\title{
HUBUNGAN PERSEPSI TERHADAP PROGRAM KESELAMATAN DAN KESEHATAN KERJA DENGAN KEPUASAN KERJA PETUGAS DAMKAR KOTA PADANG
}

\author{
Riska Asos Kariya ${ }^{1}$, Widia Sri Ardias², Nur'Aisiyah Yusri ${ }^{3}$ \\ Program Studi Psikologi Islam Fakultas Ushuluddin dan Studi Agama \\ Universitas Islam Negeri Imam Bonjol Padang \\ widiasri@uinib.ac.id
}

\begin{abstract}
Occupational safety and health is one of the factors that achieve job satisfaction. The purpose of this study is whether there is a relationship between the perception of the safety program and job satisfaction (K3) with job satisfaction. This study uses a quantitative approach that is a type of correlational research that aims to examine the extent to which variable one relates to other variables based on the correlation coefficient. The subjects of this study were Padang City Damascus officers, amounting to 65 people. Because the subject is less than one hundred, this study uses all populations for research.The results proved that Padang City Damascus Officers had a positive perception level of the K3 program, evidenced by 39 people or $60 \%$ having a positive level of perception of the K3 program, and 26 people or $40 \%$ having a negative level of perception of the K3 program and also having high level of job satisfaction, this is evidenced by as many as 47 people or $72 \%$ have a high level of job satisfaction and as many as 18 people or $28 \%$ have a low level of job satisfaction. This means that there is a relationship between the perception of the K3 program and the job satisfaction of Padang City Railroad officers.
\end{abstract}

Keywords: K3 Program, Perception, Work Satisfaction

\begin{abstract}
ABSTRAK
Keselamatan dan kesehatan kerja merupakan salah satu faktor yang mencapai kepuasan kerja. Tujuan penelitian ini adalah apakah terdapat hubungan antara persepsi terhadap program keselamatan dan kepuasan kerja (K3) dengan kepuasan kerja. Penelitian ini menggunakan pendekatan kuantitatif yang bertipe penelitian korelasional yang bertujuan untuk meneliti sejauh mana variabel satu berkaitan dengan variabel lain berdasarkan koefisien korelasi. Subjek penelitian ini adalah petugas Damkar Kota Padang yang berjumlah 65 orang. Karena subjek kurang dari seratus maka penelitian ini menggunakan semua populasi untuk penelitian.Hasil penelitian membuktikan Petugas Damkar Kota Padang, memiliki tingkat persepsi yang positif terhadap program K3, dibuktikan dengan 39 orang atau $60 \%$ memiliki tingkat persepsi terhadap program K3 yang positif, dan 26 orang atau 40\% memiliki tingkat persepsi terhadap program K3 yang negatif dan juga memiliki tingkat kepuasan kerja yang tinggi, ini dibuktikan dengan sebanyak 47 orang atau $72 \%$ memiliki tingkat kepuasan kerja yang tinggi dan sebanyak 18 orang atau $28 \%$ memiliki tingkat kepuasan kerja yang rendah. Hal ini membuktikan bahwa ada hubungan antara persepsi terhadap program K3 dengan kepuasan kerja pada petugas Damkar kota Padang.
\end{abstract}


Kata Kunci: Persepsi Terhadap Program K3, Kepuasan Kerja PENDAHULUAN

Aktivitas makhluk hidup itu beraneka ragam dan salah satu dari bentuk aktivitasnya yaitu bekerja. Bekerja berarti melaksanakan suatu tugas yang akhirnya menghasilkan sesuatu yang bisa dinikmati oleh manusia yang bersangkutan. Hal ini didorong oleh kebutuhan yang harus dipenuhi untuk kehidupan sehari-hari. Setiap karyawan yang bekerja di suatu organisasi, instansi atau industri yang ada akan memiliki perasaan positif maupun negatif tentang penilaian kerja atas apa yang telah dikerjakan. Ini merupakan dampak dari sikap positif karyawan terhadap pekerjaan dan segala sesuatu yang dihadapi didunia kerjannya. Seperti firman ALLAH SWT, Surat At-Taubah ayat 105 yang artinya:

"Dan Katakanlah, Bekerjalah kamu, Maka Allah dan rasul-Nya serta orang-orang mukmin akan melihat pekerjaanmu itu, dan kamu akan dikembalikan kepada (Allah) yang mengetahui akan yang ghaib dan yang nyata, lalu diberitakan-Nya kepada kamu apa yang Telah kamu kerjakan”.

Menurut Tafsir Al-Maragi (2010 :28) menyatakan, Dan katakanlah kepada orang orang yan bertobat itu hai rasul, bekerjalah kamu untuk duniamu dan akhiratmu, untukmu dan bangsamu, karena kerja itu adalah kunci kebahagian, bukan sekedar alasan yang dikemukakan ketika tidak berbuat apa-apa, atau sekedar mengaku giat dan bekerja keras. Menurut Robins ( 2010) kepuasan kerja adalah sikap umum seorang individu terhadap pekerjaanya. Sedangkan menurut Martihin (2010) kepuasan kerja adalah keadaan emosi yang positif dari mengevaluasi pengalaman kerja. Menurut Luthan (2011:77) Kepuasan kerja adalah hasil dari persepsi karyawan mengenai seberapa baik pekerjaan mereka memberikan hal yang dinilai penting. Seperti yang diungkapkan Asifudin (2004) bahwa nilai kerja adalah suatu konsep pandangan hidup manusia dalam bekerja untuk mencari kepuasan yang berisi segala keinginan yang dianggap baik, penting, bermanfaat, baik yang menyangkut hasil kerja maupun dalam melaksanakan pekerjaan. 
Kepuasan kerja merupakan salah satu faktor yang mempengaruhi tingkat kinerja karyawan, dengan kepuasan yang diperoleh, diharapkan kinerja karyawan yang tinggi dapat dicapai para karyawan. Tanpa adanya kepuasan kerja, maka karyawan tidak akan bekerja seperti yang diharapkan oleh instansi/ perusahaan, maka akibatnya kinerja karyawan/ petugas menjadi rendah, sehingga tujuan instansi/ perusahaan tidak akan tercapai secara maksimal. Seperti penelitian yang dilakukan oleh Baroroh (2013) dengan judul "Hubungan antara kepuasan dengan kinerja karyawan" mengatakan bahwa ada hubungan positif yang sangat signifikan antara kepuasan kerja dengan kinerja karyawan. Artinya semakin tinggi kepuasan kerja menyebabkan adanya peningkatan kinerja. Pekerja yang puas akan lebih produktif dibandingkan dengan pekerja yang tidak puas.

Bekerja sebagai petugas pemadan kebakaran merupakan salah satu hal yang sangat mulia karena pekerjaannya bertujuan untuk membantu orang lain, akan tetapi disisi lain bekerja sebagai petugas pemadam kebakaran sama saja meletakan diri didalam bahaya karena pemadam kebakaran merupakan salah satu pekerjaan yang memilki resiko kecelakaan yang sangat tinggi karena berhubungan langsung dengan situasi yang dapat membahayakan diri.

Setiap petugas pemadam kebakaran dituntut untuk memiliki sikap, kemampuan dan daya tangkap petugas yang sesuai dengan visi dan misi serta motto dalam bekerja. Sehingga setiap petugas dituntut untuk profesional dibidangnya. Setiap pekerjaan selalu mengandung potensi resiko berbahaya dalam bentuk kecelakaan kerja. Terlebih lagi pada prakteknya, petugas pemadam kebakaran bekerja dengan api yang bisa membahayakan diri mereka sendiri jika tidak dilakukan oleh petugas yang terlatih dan berpengalaman. Setiap kantor pemadam kebakaran menginginkan setiap pekerjanya memiliki kepausan kerja yang tinggi. Profesi sebagai petugas pemadam kebakaran memiliki resiko kecelakaan kerja yang sangat tinggi. Sehingga dalam bekerja petugas harus dilengkapi dengan alat-alat dan fasilitas peralatan kerja 
yang menjamin untuk melindungi petugas ketika beroperasi seperti program keselamatan dan kesehatan kerja (K3).

Riset yang dilakukan oleh badan dunia International LabourOrganization (ILO) pada tahun 2003 (ILO dalam Supardi, 2005:3) menghasilkan kesimpulan, setiap hari rata-rata 6.000 orang meninggal, setara dengan satu orang setiap 15 detik atau 2,2 juta orang per tahun akibat sakit atau kecelakaan yang berkaitan dengan pekerjaan mereka. Jumlah pria meninggal dua kali lebih banyak dibandingkan wanita, karena mereka lebih memungkinkan melakukan pekerjaan seperti membongkar zat kimia beracun (ILO dalam Supardi, 2005:3). Menurut Panggabean (2004), kecelakaan adalah suatu peristiwa yang tidak direncanakan dan harus dianalisis dari segi biaya dan sebab-sebabnya. Menurut Sugeng (2005), kecelakaan kerja adalah suatu kejadian atau peristiwa yang tidak diinginkan yang merugikan manusia, merusak harta benda atau kerugian terhadap proses. Secara umum kecelakaan kerja dibagi menjadi dua golongan. Pertama yaitu kecelakaan yang terjadi ditempat kerja karena adanya sumber bahaya atau bahaya kerja. Kedua adalah kecelakaan dalam perjalanan, yaitu kecelakaan yang terjadi diluar tempat kerja yang berkaitan dengan adanya hubungan kerja.

Bedasarkan wawancara dengan bapak S salah seorang petugas Damkar ( 2 Oktober 2018). Yaitu:

"Disini cukup sering terjadi kecelakaan kerja karena pekerjaan sebagai petugas pemadam kebakaran itu cukup berbahaya terkadang mempertaruhkan nyawa sendiri untuk menyelamatkan orang lain dan juga banyak petugas kami yang mengalami kecelakaan saat bekerja seperti terjatuh dari gedung dan menimpa temannya yang ada dibawah itu terjadi saat memadamkan api di gedung yang tinggi dan petugas yang mengalami kecelakaan terebut mengalami patah tulang dan harus cuti untuk beberapa bulan dan ada juga dari petugas kami yang meninggal dunia disaat menjalankan tugasnya, petugas tersebut mengalami tabrakan 
disaat perjalanan menuju lokasi penyelamatan, dan bukan itu saja juga banyak kecelakaankecelakaan kecil seperti terkena percikan api".

Dari wawancara diatas peneliti dapat mengatakan bahwasanya kecelakaan kerja di Damkar Kota Padang cukup tinggi karena banyak petugas yang mengalami kecelakaan disaat menjalankan tugasnya, adapun kecelakaan kerjanya itu bervariasi mulai dari kecelakaan ringan, sedang hingga berat dan ada juga sampai meninggal dunia, contohnya seperti jatuh dari gedung, terkena percikan api dan kecelakaan disaat dalam perjalanan menuju lokai penyelamatan. Berdasarkan PEMNAKER 05/MEN/1996 dan mengacu pada Undang-undang No. 1 tahun 1970 tentang kesehatan dan keselamatan kerja dapat dijadikan acuan bagi perlindungan tenaga kerja dari bahaya kecelakaan dan penyakit akibat bekerja maupun akibat lingkungan kerja. Penggunaan berbagai alat dan mesin ini menyebabkan karyawan tidak terlepas dari resiko-resiko yang menyangkut kesehatan dan keselamatannya, resiko ini dapat menimpa tenaga kerja kapan dan dimana saja, sehingga membutuhkan perhatian khusus dari berbagai pihak yang berkaitan seperti pengusaha, tenaga kerja dan manajemen. Perusahaan/Instansi yang mempekerjakan tenaga kerja sebanyak 100 orang atau lebih mempunyai potensi bahaya yang ditimbulkan oleh proses produksi yang dapat mengakibatkan kecelakaan kerja seperti peledakan, kebakaran, pencemaran dan penyakit saat bekerja, oleh sebab itu perusahaan wajib menerapkan program keselamatan dan kesehatan kerja (K3).

Keselamatan dan Kesehatan Kerja (K3) adalah suatu program yang dibuat untuk karyawan maupun pengusaha sebagai upaya mencegah timbulnya kecelakaan dan penyakit akibat kerja dengan cara mengenali hal-hal yang berpotensi menimbulkan kecelakaan dan penyakit akibat kerja dan salah satu program yang diterapkan adalah seperti pemberian jaminan kesehatan, penyuluhan tentang pentingnya kesehatan dan keselamatan kerja dan pemberian perlengkapan kerja yang berguna untuk melindungi karyawan disaat bekerja. Kesehatan kerja menurut Mangkunegara (dalam Prasetya, 2017) adalah kondisi yang menunjukan bahwa 
seorang bebas dari gangguan fisik, mental, emosi atau rasa sakit yang disebabkan oleh lingkungan kerja, sedangkan menurut Mondy (dalam Prasetya, 2017) kesehatan kerja mengacu pada pada kebebasan dari penyakit fisik maupun emosional. Keselamatan adalah kondisi aman seseorang dalam melakukan pekerjaan. Kondisi aman tersebut berasal dari internal maupun eksternal. Dari lingkungan internal adalah kemampuan seseorang dalam menjaga dirinya dan lingkungan ekternal adalah bahaya yang terjadi dari luar (Mangkunegara, 2003:159). Keselamatan dan kesehatan kerja merujuk kepada kondisi-kondisi fisiologis-fiskal dan psikologis tenaga kerja yang di akibatkan oleh lingkungan kerja yang disediakan oleh perusahaan (Rivai, 2005:411). Menurut pendapat Leon C. Megginson dalam Mangkunegara (2004), istilah keselamatan mencakup kedua istilah resiko keselamatan dan kesehatan. Keselamatan kerja menunjukan kondisi yang aman atau selamat dari penderitaan, kerusakan atau kerugian di tempat kerja. Resiko merupakan aspek-aspek lingkungan kerja yang dapat menyebabkan kebakaran, ketakutan, aliran listrik terpotong, luka memar, keseleo, patah tulang, kerugian alat tubuh seperti penglihatan dan pendengaran.

Menurut Siswanto dalam Humadydy (2014: 3), Setiap individu akan memberi arti pada setiap stimulus, akan tetapi setiap individu akan memberi arti yang berbeda pada objek yang sama, itu disebut dengan persepsi. Persepsi setiap pekerja akan berbeda, termasuk dalam mempersepsikan tentang keselamatan dan kesehatan kerja. Dari beberapa wawancara yang dilakukan peneliti pada beberapa pekerja di Damkar kota Padang dan hasilnya cukup banyak pekerja/ petugas Damkar yang menganggap bahwa pencegahan terhadap kecelakaan kerja dan penyakit kerja penting dilakukan dan ada pula sebagian kecil pekerja menganggap hal itu tidak terlalu penting untuk dilakukan (wawancara 20 september 2018). Ada banyak faktor yang mempengaruhi seseorang pada saat melakukan persepsi, diataranya yang dikemukakan oleh Bimo Walgito, yaitu fakttor-faktor yang mempengaruhi persepsi ada dua, yaitu faktor internal seperti pengalaman, perasaan, kemampuan berfikir, kerangka acuan dan motivasi, dan faktor 
eksternalnya yaitu seperti stimulus dan lingkungan (Walgito, 2003:54). Faktor-faktor tersebut dapat mempengaruhi individu pada saat melakukan persepsi, seperti pemahaman, contohnya; kurangnya pemahaman pekerja tentang adanya system dan tujuan dari $\mathrm{K} 3$, membuat mereka kurang memperhatikan akan pentingnya system manajemen $\mathrm{K} 3$, sebaliknya pekerja yang telah memahami adanya maksud dan tujuan dari system K3, mereka akan memperhatikan dan melaksanakan dengan penuh kesadaran. Selain pemahaman, pengalaman juga menjadi faktor yang dapat mempengaruhi persepsi mereka, faktor ini dapat berpengaruh kuat terhadap persepsi jika individu sudah pernah mengalaminya. Adapun tujuan dari penelitian ini adalah untuk mengetahui tingkat persepsi karyawan terhadap program keselamatan dan kesehatan kerja (K3), untuk mengetahui kepuasan kerja dan untuk mengetahui hubungan persepsi terhadap program keselamatan dan kesehatan kerja dengan kepuasan kerja petugas Damkar kota Padang.

\section{METODE PENELITIAN}

Tipe penelitian ini adalah penelitian kuantitatif, yaitu tipe penelitian yang memiliki datadata berupa angka-angka dan analisis menggunakan statistik. Menurut Sugiyono (2014: 7) metode ini sebagai metode ilmiah (scientific) karena telah memenuhi kaidah-kaidah ilmiah, yaitu konkrit atau empiris, objektif, terukur, rasional, dan sistematis.

Adapun variabel yang menjadi variabel bebas (independent variable) dalam penelitian ini adalah persepsi terhadap program keselamatan dan kesehtan kerj (K3) dan variabel terikat (dependent variable) adalah kepuasan kerja. Untuk penelitian ini teknik penarikan sampel digunakan adalah total sampling, teknik total sampling adalah teknik penentuan sampel bila semua anggota populasi digunakan sebagai sampel (Sugiono, 2010: 85). Jenis skala yang digunakan dalam penelitian adalah skala ordinal dengan bentuk skala Likert, karena sesuai dengan tujuan penelitian untuk mengukur sikap subjek terkait variabel yang diteliti. Menurut 
Riduan (2010: 12), skala Likert digunakan untuk mengukur sikap, pendapat, dan persepsi seseorang atau sekelompok orang tentang gejala sosial.

Skala pengukuran yang digunakan dalam penelitian ini adalah skala persepsi terhadap program K3 dan skala kepuasan kerja yang dibuat sendiri oleh peneliti. Skala persepsi diambil dari teori Walgito yang terdiri dari beberapa aspek, yaitu kognitif, afektif, dan konatif. Adapun skala kepuasan kerja diambil dari teori McClelland yang terdiri dari beberapa dimensi, yaitu pekerjaan itu sendiri, atasan, teman sekerja, promosi dan gaji. Berikut adalah tabel hasil uji coba skala penelitian.

Tabel 1. Hasil Uji Coba Skala Persepsi Terhadap Program K3

\begin{tabular}{|c|c|c|c|c|}
\hline No & Aspek & Indikator & Shahih & Gugur \\
\hline \multirow[t]{2}{*}{1} & \multirow[t]{2}{*}{ Aspek kognitif } & $\begin{array}{l}\text { Pemikiran (proses mencari makna untuk } \\
\text { mendapatkan keputusan mengenai metode } \\
\text { penerapan program } \mathrm{K} 3 \text { ) }\end{array}$ & $\begin{array}{l}1,11,6 \\
16\end{array}$ & $\begin{array}{l}21,26, \\
30,34\end{array}$ \\
\hline & & $\begin{array}{l}\text { Penilaian (mengambil keputusan terhadap } \\
\text { sesuatu dengan ukuran baik dan buruk } \\
\text { mengenai penerapan program K3 }\end{array}$ & $\begin{array}{l}2,12,22 \\
31,7,27 \\
35,39\end{array}$ & 17 \\
\hline \multirow[t]{2}{*}{2} & \multirow[t]{2}{*}{ Aspek afektif } & $\begin{array}{l}\text { Emosional (gejolak perasaan positif } \\
\text { terhadap penerapan program K3) }\end{array}$ & $\begin{array}{l}3,13,23 \\
\quad 8,18\end{array}$ & - \\
\hline & & $\begin{array}{l}\text { Sikap mendukung (sikap suka terhadap } \\
\text { penerpan program K3) }\end{array}$ & $\begin{array}{c}4,14,24, \\
32,40,41, \\
42,9,19, \\
28,36,38\end{array}$ & - \\
\hline 3 & Aspek konatif & $\begin{array}{l}\text { Perilaku positif (adalah tindakan baik } \\
\text { seseorang terhadap penerapan program K3) }\end{array}$ & $\begin{array}{l}5,15,25 \\
33,10,20 \\
29,37\end{array}$ & - \\
\hline & & Total & 37 & 5 \\
\hline
\end{tabular}


Tabel 2. Hasil Uji Coba Skala Kepuasan Kerja

\begin{tabular}{|c|c|c|c|c|}
\hline No & Aspek & Indikator & Shahih & Gugur \\
\hline \multirow[t]{2}{*}{1.} & \multirow[t]{2}{*}{$\begin{array}{c}\text { Pekerjaan itu } \\
\text { sendiri }\end{array}$} & $\begin{array}{l}\text { Memiliki kesesuaian dalam } \\
\text { bekerja }\end{array}$ & $33,9,25$ & $1,17,41$ \\
\hline & & $\begin{array}{l}\text { Memiliki sikap tanggung } \\
\text { jawab terhadap pekerjaan }\end{array}$ & $\begin{array}{l}2,18,34 \\
10,26,42\end{array}$ & \\
\hline 2. & Atasan & $\begin{array}{l}\text { Memiliki hubungan baik } \\
\text { dengan atasan }\end{array}$ & $\begin{array}{l}19,35,49, \\
63,68,71, \\
73,74,11, \\
27,53,60, \\
65,66,69, \\
70,75,76\end{array}$ & $3,57,43$, \\
\hline \multirow[t]{2}{*}{3.} & \multirow[t]{2}{*}{ Teman kerja } & $\begin{array}{l}\text { Memiliki Interaksi yang } \\
\text { baik sesama karyawan }\end{array}$ & $\begin{array}{c}20,36,50 \\
12,28,44, \\
54,61\end{array}$ & 4 \\
\hline & & $\begin{array}{l}\text { Mampu untuk bekerjasama } \\
\text { dengan baik }\end{array}$ & $\begin{array}{c}37,51,59, \\
13,29,45, \\
55,62\end{array}$ & 5,21 \\
\hline 4. & Promosi & Kesempatan untuk maju & $\begin{array}{c}6,22,38 \\
52,14,30 \\
46,56\end{array}$ & \\
\hline \multirow[t]{2}{*}{5.} & \multirow[t]{2}{*}{ Gaji } & $\begin{array}{l}\text { Memperoleh gaji yang } \\
\text { sesuai }\end{array}$ & $\begin{array}{l}23,39,64 \\
15,31,47 \\
72\end{array}$ & $7,67,58$ \\
\hline & & $\begin{array}{l}\text { Memperoleh jaminan sosial } \\
\text { sesuai dengan yang } \\
\text { diharapkan }\end{array}$ & $\begin{array}{l}24,16, \\
32,48\end{array}$ & 8,40 \\
\hline & & Iumlah & 62 & 14 \\
\hline
\end{tabular}

Berdasarkan hasil uji coba skala penelitian di atas, diketahui bahwa skala tersebut reliabel dan layak digunakan menjadi instrumen penelitian.Berikut adalah tabel hasil uji reliabilitas skala yang digunakan. 


\section{Tabel 3. Hasil Uji Reliabilitas Skala Persepsi Terhadap Program K3}

Reliability Statistics

\begin{tabular}{|c|c|}
\hline Cronbach's Alpha & N of Items \\
\hline, 865 & 42 \\
\hline \multicolumn{2}{|c|}{ Sumber: SPSS 20.0 } \\
\hline \multicolumn{2}{|c|}{. } \\
\hline \multicolumn{2}{|c|}{}
\end{tabular}

Sumber: SPSS 20.0

Tabel 4. Hasil Uji Reliabilitas Skala Kepuasan Kerja

\section{Reliability Statistics}

\begin{tabular}{|c|c|}
\hline Cronbach's Alpha & N of Items \\
\hline ,929 & 76 \\
\hline \multicolumn{2}{|c|}{ Sumber: SPSS 20.0 }
\end{tabular}

\section{HASIL PENELITIAN}

Berdasarkan tabel diatas dapat dilihat koefisien reliabilitasnya adalah sebesar 0,865 dan 0,929. Menurut Syaifuddin Azwar, reliabilitas telah dianggap memuaskan apabila koefisiennya mencapai $0,700-0,900$, artinya bahwa skor skala yang kita peroleh mampu mencerminkan 70\%-90\% skor murni atau skor yang sesungguhnya. Jadi, skor koefisien reliabilitas skala Persepsi Terhadap Program K3 sebesar $\mathrm{r}=0,865$ dan skor koefisien reliabilitas skala Kepuasan Kerja sebesar $\mathrm{r}=0,929$ yang artinya bahwa kedua skala mencerminkan skor yang sesungguhnya.

Tabel 5. Rumus Kategorisasi

\begin{tabular}{|c|c|}
\hline Rumus & Kategorisasi \\
\hline $\mathrm{x}<(\mu-1,0 \sigma)$ & $\begin{array}{c}\text { Kategori } \\
\text { Rendah }\end{array}$ \\
\hline$(\mu+1,0 \sigma) \leq \mathrm{x}$ & $\begin{array}{c}\text { Kategori } \\
\text { Tinggi }\end{array}$ \\
\hline
\end{tabular}

Rumus kategori di atas dijadikan acuan untuk menentukan kategori persepsi terhadap program K3 dan kategori kepuasan kerja petugas DAMKAR Kota Padang. Kategorisasi berdasarkan hasil penelitian tersebut dapat digambarkan oleh tabel berikut. 
Tabel 6. Hasil Kategorisasi

\begin{tabular}{|c|c|c|c|c|}
\hline No & Kategorisasi & Rentang & Jumlah & Persentase \\
\hline 1 & Rendah & $87-114$ & 26 & $40 \%$ \\
\hline 2 & Tinggi & $115-142$ & 39 & $60 \%$ \\
\hline \multicolumn{2}{|c|}{ Jumlah } & 65 & $100 \%$ \\
\hline
\end{tabular}

Tabel 7. Hasil Kategorisasi Kepuasan Kerja

\begin{tabular}{|c|c|c|c|c|}
\hline No & Kategorisasi & Rentang & Jumlah & Persentase \\
\hline 1 & Rendah & $178-199$ & 18 & 28 \\
\hline 2 & Tinggi & $200-221$ & 47 & 72 \\
\hline \multicolumn{2}{|c|}{ Jumlah } & 65 & $100 \%$ \\
\hline
\end{tabular}

\section{DISKUSI}

Deskripsi data penelitian digunakan untuk membuat kategorisasi variabel dengan menggolongkan subjek dalam dua kategori yaitu rendah dan tinggi. Menurut Azwar (2005:103), skor skala sebagai hasil ukur berupa angka (kuantitatif) maka skor memerlukan suatu norma pembanding agar dapat diinterpretasikan secara kualitatif. Berdasarkan tujuan tersebut maka peneliti menetapkan suatu kategorisasi sesuai rumus berikut.

Berdasarkan hasil kategorisasi persepsi terhadap program K3 didapatkan bahwa dari 65 subjek yang diteliti, 39 orang atau $60 \%$ memiliki tingkat persepsi terhadap program K3 yang tinggi, 26 orang atau $40 \%$ memiliki tingkat persepsi terhadap program K3 yang rendah. Dari besaran persentase persepsi terhadap program K3 petugas Damkar Kota Padang lebih dominan memiliki tingkat persepsi terhadap program K3 yang dikategorikan tinggi. Hal ini mengindikasi bahwa sebagian besar dari petugas Damkar Kota Padang memiliki tingkat persepsi terhadap program K3 yang tinggi. Seorang petugas dikatakan memiliki persepsi terhadap program K3 yang tinggi ketika individu itu mampu untuk berperilaku positif terhadap program yang diterapkan di tempat bekerjanya dan merasa nyaman dan aman ketika melakukan pekerjan, baik itu berisiko maupun tidak berisiko . Seperti yang dikatan oleh Bimo Walgito faktor yang mempengaruhi seseorang pada saat melakukan persepsi, yaitu faktor internal 
seperti pengalaman, perasaan, kemampuan berfikir, kerangka acuan dan motivasi, dan faktor eksternalnya yaitu seperti stimulus dan lingkungan (Walgito, 2003:54).

Tinggi rendahnya tingkat persepsi terhadap program K3 petugas Damkar Kota Padang dapat dilihat melalui tinggi rendahnya skor yang diperoleh pada skala persepsi terhadap program K3. Semakin tinggi skor yang diperoleh petugas pada skala persepsi terhadap penerapan program K3 maka semakin tinggi pula tingkat persepsi terhadap penerapan program K3 yang dimiliki oleh petugas Damkar Kota Padang.

Berdasarkan hasil kategorisasi kepuasan kerja dapat diketahui bahwa didapatkan 65 subjek yang diteliti, sebanyak 47 orang atau 72\% memiliki tingkat kepuasan kerja yang tinggi dan sebanyak 18 orang atau 28\% memiliki tingkat kepuasan kerja yang rendah. Dari besaran persentase kepuasan kerja pada tabel tersebut, menunjukan bahwa kepuasan kerja petugas Damkar Kota Padang memiliki kepuasan kerja yang dikategorikan tinggi. Kepuasan kerja ini sangatlah berpengaruh terhadap sikap seseorang dalam bekerja, dimana akan menunjukan perilaku-perilaku yang sesuai dengan aspek-aspek yang terkait dengan kepuasan kerja tersebut. kepuasan kerja ini juga dipengaruhi oleh faktor internal dan ekternal, sesuai dengan yang dijelaskan oleh As'ad, 2004 (dalam Anggraeni \& Santosa) ada beberapa faktor pemicu yang akan mempengaruhi kepuasan kerja seperti, faktor psikologis yang berhubungan dengan kejiwaan karyawan yang meliputi minat, ketentraman dalam bekerja, bakat dan keterampilan. Faktor sosial yang meliputi interaksi sosial antar sesama karyawan ataupun dengan atasan. Faktor fisik yang berhubungan dengan jenis pekerjaan, pengaturan waktu kerja, kenyamaan dalam bekerja, kondisi kesehatan karyawan dan usia karyawan. Serta faktor keungan yaitu faktor yang berhubungan dengan jaminan sosial, gaji, tunjangan-tunjangan, promosi dan fasilitas yang diberikan. Setiap orang akan memiliki persepsi yang berbeda tentang makna kerja. Suatu pekerjaan akan mempunyai makna bagi seseorang apabila pekerjaan tersebut dapat memenuhi kebutuhannya secara maksimum dan memuaskan. Semakin banyak aspek dalam 
pekerjaan yang sesuai dengan keinginan seseorang, maka akan semakin tinggi kepuasan kerja orang tersebut.

Tinggi rendahnya tingkat kepuasan kerja seorang petugas Damkar Kota Padang dapat dilihat melalui tinggi rendahnya skor yang diperoleh pada skala kepuasan kerja. Semakin tinggi skor yang diperoleh petugas Damkar Kota Padang pada skala kepuasan kerja maka semakin tinggi pula tingkat kepuasan kerja yang dirasakan oleh petugas tersebut. sebaliknya, semakin rendah skor yang diperoleh petugas pada skala kepuasan kerja maka semakin rendah pula tingkat kepuasan kerja pada petugas tersebut.

Melalui hasil olah data penelitian yang dilakukan, penulis dapat menyimpulkan bahwa terdapat hubungan persepsi terhadap program K3 dengan kepuasan kerja. Ini dapat dibuktikan berdasarkan hasil analisis data yang telah dilakukan, yaitu :

a. Uji Linearitas

Uji Linearitas merupakan uji persyarat yang bisa dilakukan jika akan melakukan analisis korelasi atau regresi linear. Uji linearitas bertujuan untuk mengetahui apakah dua variabel penelitian secara signifikan mempunyai hubungan yang liniear atau tidak. Kedua variabel dikatakan liniear apabila memiliki taraf signifikansi kecil dari 0,05 atau $\mathrm{P}<0,05$ (Priyatno, 2014:79).

Berdasarkan uji linieritas pada SPSS versi 20.0 for windows dapat diketahui bahwa nilai $\mathrm{F}=62,131$ dan nilai $\mathrm{P}$ sebesar $0,000(\mathrm{P}<0,05)$, maka dapat disimpulkan bahwa antara variabel persepsi terhadap program K3 dan kepuasan kerja terdapat hubungan yang linear, maka asumsi linearitas terpenuhi.

b. Uji Normalitas

Uji normalitas bertujuan untuk mengetahui apakah populasi data terdistribusi normal atau tidak. Distribusi data yang normal menyatakan bahwa subjek penelitian tergolong representatif atau dapat mewakili populasi yang ada, sebaiknya apabila sebaran tidak 
normal, maka dapat disimpulkan bahwa subjek tidak representatif atau tidak mewakili populasi yang ada. Uji normalitas dalam penelitian ini menggunakan uji one sample kalmogorov smirnov, dapat dinyatakan terdistribusi normal jika signifikansi besar dari 0,05 (Priyatno, 2012). Berdasarkan pengolahan data dengan menggunakan SPSS versi 20.0 for windows, maka diperoleh hasil uji normalitas sebagai berikut:

\section{Tabel 8. Uji Normalitas Sebaran Skala Persepsi Terhadap Program K3 dengan Kepuasan Kerja}

\begin{tabular}{|c|c|c|}
\hline Variabel & $\begin{array}{c}\text { Kolmogorov- } \\
\text { Smirnov Z }\end{array}$ & $\begin{array}{c}\text { Asymp } \\
\text { Sig }\end{array}$ \\
\hline $\begin{array}{c}\text { Persepsi } \\
\text { Terhadap } \\
\begin{array}{c}\text { Program } \\
\text { K3 }\end{array}\end{array}$ & 0,409 & 0,996 \\
\hline $\begin{array}{c}\text { Kepuasan } \\
\text { Kerja }\end{array}$ & 1,257 & 0,085 \\
\hline
\end{tabular}

Sumber: Data SPSS 20.0 for windows

Untuk mengetahui data terdistribusi normal atau tidak, kita dapat mengetahui dari tabel One Sample Kolmogorov Smirnov test di atas. Kriteria pengujiannya adalah apabila nilai signifikansi besar dari 0,05 maka data terdistribusi normal. Dari tabel di atas, dapat kita ketahui bahwa nilai KS untuk persepsi terhadap program K3 adalah 0,409 dan untuk nilai signifikansinya adalah $0,996(\mathrm{P}>0,05)$ yang berarti variabel persepsi terhadap program $\mathrm{K} 3$ berdistribusi normal. Sedangkan nilai KS untuk kepuasan kerja adalah 1,257 dan nilai signifikansinya adalah 0,085 (P.0,05) yang berarti variabel kepuasan kerja berdistribusi normal. Jadi dapat disimpulkan bahwa pada skala persepsi terhadap program K3 berdistribusi normal dan pada skala kepuasan kerja juga berdistribusi normal.

c. Uji Hipotesis

Uji hipotesis dilakukan dengan menggunakan analisis korelasi Pearson untuk mengetahui ada atau tidaknya hubungan regulasi emosi dengan penerimaan sosial. Berdasarkan hasil perhitungan dengan menggunakan program SPSS versi 20.0 for windows dapat diperoleh sebagai berikut: 
Tabel 9. Uji Hipotesis Sebaran Skala Persepsi Terhadap Program K3 dan Kepuasan Kerja

\begin{tabular}{|c|c|c|}
\hline Variabel & correlations & Sig \\
\hline $\begin{array}{c}\text { Persepsi terhadap program K3 }- \\
\text { Kepuasan kerja }\end{array}$ & 0,690 & 0,000 \\
\hline
\end{tabular}

Sumber: SPSS 20.0 for windows

Hasil analisis pada di atas menunjukkan bahwa nilai koefisien pearson correlation persepsi terhadap program K3 dengan kepuasan kerja sebesar 0,690 dengan nilai signifikansi $0,000(\mathrm{P} \leq 0,05)$ berarti hipotesis Ha diterima. Jika nilai signifikansi $<0,05$ berarti Ha diterima sedangkan jika nilai signifikansi $>0,05$ berarti hipotesis Ho ditolak, dan nilai signifikansi dari persepsi terhadap program K3 dengan kepuasan kerja $0,000(0,000<0,05)$. Sehingga dapat disimpulkan bahwa ada hubungan antara persepsi terhadap program K3 dengan kepuasan kerja petugas Damkar Kota Padang.

Berdasarkan analisis yang diperoleh bahwa persepsi terhadap program K3 memiliki hubungan yang signifikan dengan kepuasan kerja. Dengan demikian hipotesis dalam penelitian ini dapat diterima. Petugas DAMKAR Kota Padang memiliki persepsi terhadap program K3 yang tinggi, dan memiliki kepuasan kerja yang tinggi. Artinya, persepsi terhadap Program K3 memberikan banyak pengaruh untuk meningkatkan kepuasan kerja.

\section{KESIMPULAN DAN SARAN}

Berdasarkan hasil penelitian yang telah dilakukan dan pengujian hipotesis mengenai hubungan persepsi terhadap program K3 dengan kepuasan kerja petugas Damkar Kota Padang, maka dapat disimpulkan bahwa petugas damkar kota Padang, memiliki tingkat persepsi terhadap program K3 yang positif dan memiliki kepuasan kerja yang tinggi dan hal ini menunjukan terdapat hubungan antara persepsi terhadap program K3 dengan kepuasan kerja petugas Damkar Kota Padang. Sehingga semakin positif tingkat persepsi terhadap program K3, maka semakin tinggi tingkat kepuasan kerja petugas Damkar Kota Padang. Sebaliknya, 
semakin negatif persepsi terhadap program K3, maka semakin rendah pula tingkat kepuasan kerja pada petugas Damkar Kota Padang.

Berdasarkan hasil penelitian yang telah dilakukan, maka peneliti memberikan saran yang dapat dijadikan sebagai pertimbangan dan diharapkan dapat bermanfaat, di antaranya pada karyawan/ petugas diharapkan dapat lebih berhati-hati dalam menjalankan tugas, sebab walaupun sudah menggunakan pelaralatan K3 yang lengkap tetap saja kecelakaan dapat terjadi. Salah satu cara yang dapat dilakukan yaitu harus mampu bertanggung jawab atas pekerjaan dan yang paling utama mampu untuk bertanggung jawab pada diri sendiri agar tidak merugikan diri sendiri dan orang lain.Bagi Peneliti selanjutnya diharapkan dapat melakukan penelitian dengan ruang lingkup yang lebih luas dan memberikan beberapa variasi yang berbeda untuk mendapatkan hasil dan kesimpulan yang lebih komprehensif. Penelitian berikutnya dapat dilakukan di lokasi dan responden yang berbeda karakteristiknya, misalnya dengan memperhatikan karaktertik gender pada penelitiannya.

\section{DAFTAR PUSTAKA}

Afani, M Zailal. (2008). Hubungan Persepsi Lingkungan Kerja dengan Kepuasan Kerja Karyawan di Perusahaan Daerah Air Minum (PDAM) Kota Madiun. Fakultas Psikologi Universitas Malang.

Anggraini, V., Prasmatiwi, F. E., dan Santoso, H. (2013). Tingkat Kepuasan dan Loyalitas Konsumen Gulaku di Kota Bandar Lampung. Jurnal Ilmu-ilmu Agribisnis, Volume 1 No.2.

Arikunto, S. (2010). Prosedur Penelitian Suatu Pendekatan Praktik. Jakarta: Rineka Cipta.

Arikunto, Suharsimi, (2006). Prosedur penelitian suatu pendekatan praktik: Jakarta. PT Rineka Cipta.

Azwar, S. (2005). Metode Penelitian. Yogyakarta: Pustaka Belajar Offset.

Azwar, S. (2010). Metode Penelitian. Yogyakarta: Pustaka Belajar.

Azwar, S. (2013). Penyusunan Skala Psikologi. Yogyakarta: Pustaka Pelajar.

Azwar, S. (2012). Penyusunan Skala Psikologi. Yogyakarta: Pustaka Pelajar.

Azwar, S. (2012). Reliabilitas dan Validitas. Yogyakarta: Pustaka Pelajar

Bimo, Walgito. (2003). Pengantar Psikologi Umum, Yogyakarta : ANDI

Baroroh Septiani. 2013. Hubungan Kepuasan Kerja dengan Kinerja Karyawan. Fakultas Psikologi Universitas Muhammadiyah Yogyakarta

Chaplin, J. P. (2009), Dictionary Of Psychology, (Terjemah. Kartini Kartono) Jakarta: PT. Raja Grafindo Persada.

Diahsari, Erita Y. (2016). Pengantar Psikologi Industri Dan Organisasi. Yogyakarta: UAD Press. 
Hasanah Uswatun, Hafd Moch. (2016). Persepsi Lingkungan Kerja Psikologis Terhadap Kepuasan Kerja. Fakultas Psikologi Universitas Darul'Ulu.

http/ Kbbi. Web. Id/ Pemadam Kebakaran

Humaydi Rusdy. (2014). Hubungan Antara Persepsi K3 dengan Kepuasan Kerja Karyawan Bagian Produksi PT Dharma Anugerah Indah Surabaya. Program studi Psikologi Universitas Isalam Negri Sunan Kalijaga.

Kasmir. (2016). Manajemen Sumber Daya Manusi (Teori dan Praktik). Jakarta: PT Raja Grafindo Persada.

Luthans, Freud. (2011). Organizational Beahavior : An Evidence-Based Approach. New York: McGraw-Hill.

Nurjahjanti Harlina. (2010). Hubungan Antara Persepsi Terhadap Kompensasi dan Semangat Kerja Pada Kryawan Operasional PT KAI (Persero) Purwokerto. Fakultas Psikologi Universitas Dipenegoro.

Nurjaman, Kadar 2014. MenajemenPersonalia. Bandung: CV PustakaSetia.

Pareke, F. Js.( 2004). Kepemimpinan Transformasional dan Perilaku Kerja Bawahan: Sebuah Agenda Penelitian, Jurusan Manajemen Fakultas Ekonomi Universitas Bengkulu.

Rakhmat, Jalaludin, (2005). Psikologi Komunikasi. Bandung: PT. Remaja Rosdakarya.

Veithzal Rivai (2004). Manajemen Sumer Daya Manusia Untuk Peruahaan. Jakarta: PT Raja Grafindo Persada.

Yusuf,M. (2014). Metode Penelitian. Jakarta:Prenadamedia Group

Sapardi , 2005. Metode Penelitian Ekonomi dan Bisnis. Yogtakarta:UII Pres

Sumiwi Rari Arinta, Maria Carolina. (2016). Hubungan Minat Terhdap Pekrjaan dengan Kepuasan Kerja Pada Karyawan PT. Plambo Pemalang. Universitas Khatolik Soegijapranata. 